\title{
The Effects of Molybdenum and Manganese on the Mechanical Properties of Austempered Ductile Iron
}

\author{
Nikša ČATIPOVIĆ, Dražen ŽIVKOVIĆ, Zvonimir DADIĆ
}

\begin{abstract}
In this review paper an insight is given on how alloying elements and heat treatment parameters affect mechanical properties of austempered ductile irons (ADI).To elevate hardenability or austemperability of large sections, alloying is required during production of ADI. Conventional ductile iron should be enriched with certain alloying elements to obtain ADIs with desired strength and ductility. These elements must ensure that pearlite formation is avoided as well as that austenite is stabilized during the austempering heat treatment. It has been shown that both single alloying elements and also combinations of different alloying elements affect the mechanical properties of ADI. Also, it has been shown that strength, hardness, elongation and fracture toughness strongly depend on the amount of ausferritic ferrite and stable, high carbon enriched retained austenite. A combination of $\mathrm{Ni}, \mathrm{Cu}, \mathrm{Mn}$ and $\mathrm{Mo}$ is usually added. To increase hardenability of ductile irons,Mo should be added. Addition of $\mathrm{Mn}$ in ductile irons may influence tensile strength and hardenability of ADIs. During the selection of chemical composition, both for Dls and ADIs, alloying elements which negatively affect casting quality, such as formation of non-spheroidal graphite, inclusions and carbides should be limited. The standard processing window depends on the austempering parameters and alloying elements, as well as the method used to produce ADI.
\end{abstract}

Keywords: alloying elements; austempered ductile iron; austempering parameters; ductile iron; mechanical properties

\section{Introduction}

In previous years, there was great demand for lighter, durable and cost effective materials. Ductile iron is one such material. A lot of research has been done on this material and focus has been set on improving mechanical properties using adequate heat treatment and alloying elements. When ductile iron is subjected to an isothermal heat treatment, known as "austempering", Austempered Ductile Iron (ADI) is produced, [1]. It exhibits superior properties to ductile iron.

ADI materials possess a unique microstructure of ausferrite, produced by austempering of ductile irons. The ausferrite is a mixture of fine acicular ferrite and carbon enriched stabilized austenite, [2, 3]. Capabilities of such newly formed microstructure are far superior to many ferrous and aluminium alloys. When compared to pearlitic, ferritic or even martensitic structures, ausferrite exhibits twice the strength for a given level of ductility formed by conventional heat treatment, [1].
The mechanical properties of ADI depend on the ausferrite microstructure. The ausferrite matrix offers higher tensile strength to ductility ratio than any other grade of ductile iron. Different combinations of properties can be achieved from ADI because of the ausferrite microstructure which depends on both heat treatment parameters and alloying elements, [4].The austempering heat treatment consists of austenitising ductile iron, quenching to the austempering temperature for a controlled period of time, and then cooling to room temperature, Fig. 1.

Several authors $[2,3,6]$ have shown that during the austempering, ADI is submitted to a two stage transformation process. In the first stage, the austenite $(\gamma)$ decomposes into bainitic ferrite $(\alpha)$ and a carbon enriched retained austenite $\left(\gamma_{\mathrm{hc}}\right)$, known as ausferrite.

$$
\gamma \rightarrow \alpha+\gamma_{h c}
$$

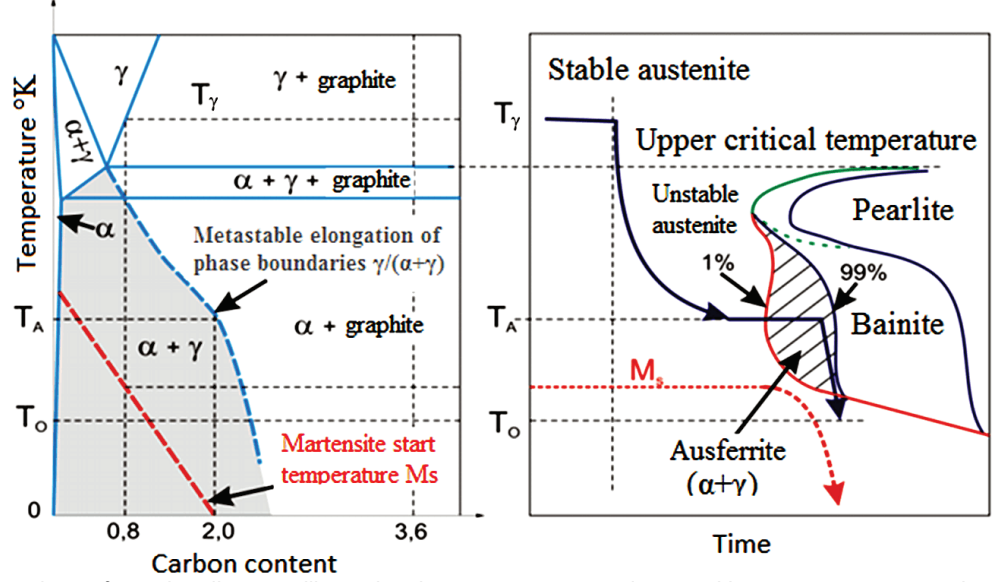

Figure 1 Principle phase and isothermal transformation diagrams illustrating the $M_{\mathrm{S}}$ temperature change with respect to austempering time and the metastable $\alpha+\gamma$ region [5]

Carbon enriched retained austenite $\left(\gamma_{\mathrm{hc}}\right)$ further decomposes into ferrite $(\alpha)$ and carbides if the material is held at the austempering temperature for too long, [2].

$$
\gamma_{h c} \rightarrow \alpha+\text { carbide }
$$


The occurrence of carbides in the microstructure makes the material brittle and therefore that reaction should be avoided. Hence, the optimum mechanical properties of ADI material can be achieved upon completion of the first reaction, but before the second reaction starts, i.e. inside the processing window, $[7,8]$.

The investigation and determination of a processing window has attracted great interest in previous years, [3], $[6,11-15]$.A processing window can be defined as a "microstructure" or "standard" processing window. A "microstructure" processing window is defined by microstructural features and it is best determined with the criterion proposed by Elliott and Bayati, [3, 15]. The beginning of the processing window represents a point when the unreacted austenite volume decreases to $3 \%$ (value obtained using quantitative metallography), while the end of the window is correlated to a decrease of reacted (carbon enriched) retained austenite volume $(V \gamma)$ to $90 \%$ of its maximum (where $V \gamma$ was determined by Xray diffraction), [8]. On the other hand, "standard" processing window is defined regarding mechanical properties of ADI material produced in microstructure processing window, which have to satisfy ASTM A897M:1990 standard. However, there are three ADI standards used currently worldwide: ASTM A897M-06 (first edition from 1990), EN 1564:1997 and ISO $17804: 2005$, [16]. As those standards vary in some details regarding the number of grades and minimal requirements of ultimate tensile strength and elongation for different grades, the processing window will differ and depend on the standard used, [8].

Alloying elements have influence on the isothermal temperature, initiation time and completion of the austempering reaction, and thereby affording a larger processing window and ease of control of the reaction. The influence of copper and nickel is of interest in this respect. Copper delays nucleation of ferrite plates around graphite nodules and favours the formation of plate-like morphology. Furthermore, $\mathrm{Cu}$ suppresses the formation of carbides in the microstructure. Presence of nickel reduces the transformation speed and lowers the temperature of the isothermal reaction. The synergetic effect of $\mathrm{Cu}$ and $\mathrm{Ni}$ on suppressing the nucleation and early growth of ferrite plates and thus expanding the time for isothermal reaction is especially important, $[8,9,10]$.

\section{Austempered Ductile Iron (ADI)}

ADI has almost twice the strength of pearlitic ductile iron with high elongation and toughness. Material with these properties has superior wear resistance and fatigue strength, [1]

Austempering heat treatment of steel was developed by Baint, et al, in the early 1930's. In the early 1940's Flinn applied austempering process on cast iron, particularly grey cast iron. In the 1950's, both the austempering process and ductile iron were developed, [17-20].

During austempering, austenite reduces its distortion and cracking as a result of isothermal transformation to lower bainite, [21]. During this heat treatment process, the steel is heated to the austenitizing temperature and then quenched in a molten salt bath at a temperature above $M s$ and so that the austenite can transform to lower bainite, [22].

When the steel is quenched from $A 1$ temperature (temperature above which austenite is formed) to the molten salt bath sufficient hardenability of the steel is required to avoid pearlitic transformation. Austempering process results in increased ductility, toughness, hardness but also lower distortion and quench cracks when compared to a tempered sample.

ADI provides excellent combination of high strength and good ductility, good fatigue strength and high wear resistance along with good fracture toughness. Different properties can be obtained by varying the austempering variables i.e. austempering temperature and holding time, [23].

As mentioned in the introduction, ADI microstructure differs from austempered steels where the microstructure consists of ferrite and carbide. In ADIs, result of austempering is referred to as "ausferrite" rather than bainite, [23]. The addition of silicon suppresses the carbide precipitation during the austempering and retains high carbon enriched austenite $\left(\gamma_{\mathrm{hc}}\right)$. During the austempering of steel, diffusion of carbon into the residual austenite occurs thus forming bainitic ferrite. As the process continues, more bainite transforms and higher amount of carbon diffuses into the surrounding austenite. In the beginning, martensitic transformation occurs because the austenite carbon content is not enough to make it stable, but over longer periods of time it becomes thermally stable, [23, 24, 25].

ADI produced by the austempering of the ductile iron undergoes the following steps:

1) Austenitising: Heating of ductile iron to the austenitising temperature $\left(850-950{ }^{\circ} \mathrm{C}\right)$ thus converting microstructure to austenite.

2) Austempering: Quenching austenitized part in a molten salt bath so that pearlitic transformation is avoided. Salt bath is maintained at a temperature between $200-450{ }^{\circ} \mathrm{C}$.

3) Holding time: Ductile iron is held at the desired temperature for sufficient period of time thus allowing completion of bainitic transformation.

4) Air cooling: Removing samples from salt bath and air cooling to room temperature.

The usage of ADI parts is very broadly based on the properties and cost and flexibility:

1) Agriculture: excellent soil wear resistance.

2) Digger/grab teeth: high strength and wear resistance.

3) Industrial: wear components, pumps etc.

4) Gears: wear resistance and vibration damping.

5) Construction: crushing, grinding, wear resistant components etc.

6) Food processing: milling, grinding, mixing, palletisation etc.

ADI has also found successful application in automotive industry, heavy trucks and railways.

The major disadvantage of ADI is its poor weldability, [26, 27, 28].

By adding alloying elements high-temperature reaction products can be avoided (such as pearlite in larger section sizes) or to improve mechanical properties, 
especially hardenability. These alloying elements are copper, nickel, molybdenum and manganese, [29]. During solidification these alloying elements tend to segregate therefore uniform distribution can't exist in the matrix. This has a potentially detrimental effect on the austempering reaction and therefore on mechanical properties, mostly impacting toughness and ductility.

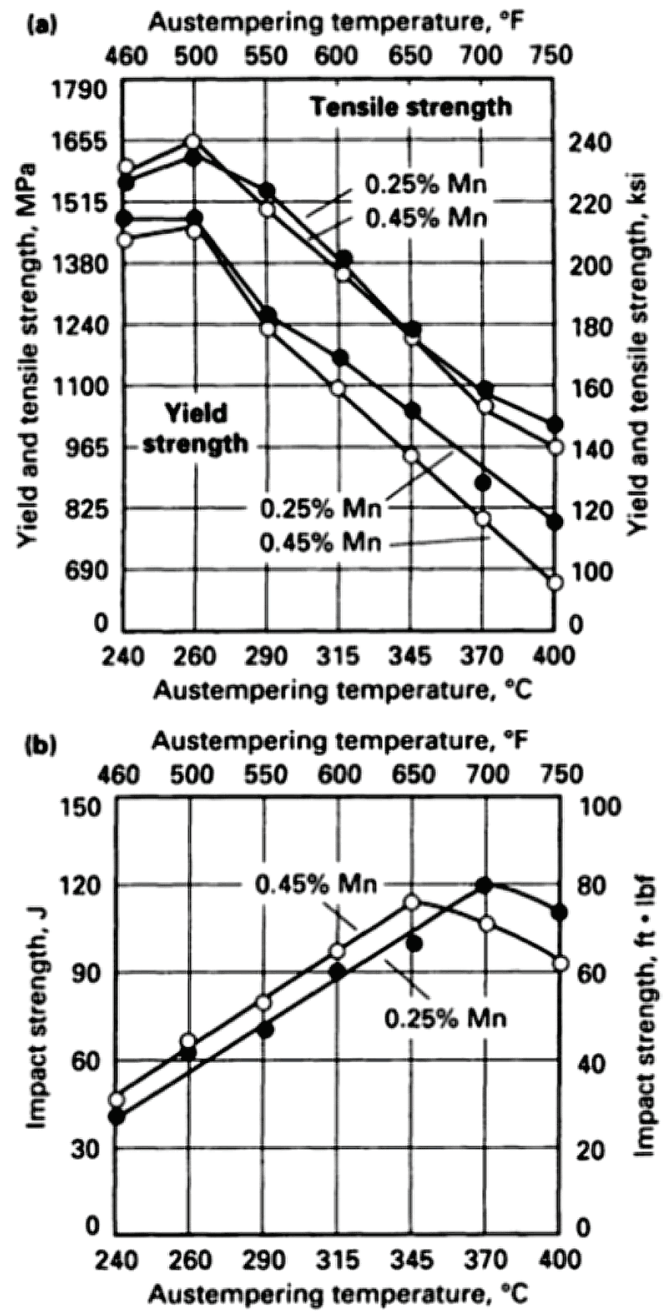

Figure 2 Effect of austempering temperature on properties of ductile iron: (a) Yield strength and tensile strength (b) Impact strength [29]

Manganese and molybdenum greatly affect hardenability of pearlite but also segregate and freeze into intercellular regions of the material where they promote iron or alloy carbides. While copper and nickel usually do not affect hardenability to the same extent, they tend to segregate to graphite nodules and do not form detrimental carbides. Combinations of aforementioned elements are selected for their synergistic effect on hardenability, [29]. Also of importance are the heat treatment parameters which greatly influence the final mechanical properties of ADI and the microstructure. The matrix carbon content increases with the increase of austenitizing temperature. The actual matrix carbon content in a complex way depends on the alloying elements, their amount and location within the matrix, [29].

The silicon content is the most important determinant of matrix carbon content in ductile irons. As silicon content increases, the carbon content in the matrix decreases. Austenitizing temperatures between $845{ }^{\circ} \mathrm{C}$ and $925^{\circ} \mathrm{C}$ are normal, for most of the sample sizes, and austenitizing times of approximately $2 \mathrm{~h}$ have been shown to be sufficient to fully recarburize the matrix, [29]. The higher austenitizing temperature with its carbon content promotes increased hardenability, which causes a slower rate of isothermal austenite transformation.

The austempering temperature is the primary determinant of the final microstructure and therefore the hardness and strength of austempered product. As the austempering temperature increases, the strength and impact toughness vary as shown in Fig. 2 for irons with two levels of manganese. The maximum value of ductility at any given austempering temperature is a function of time, as shown in Fig. 3 for a number of ductile cast iron alloys, [29]. The initial increase in elongation occurs as stage I transformation completes, where the fraction of retained austenite is at the maximum. Further austempering reduces ductility as the stage II transformation causes decomposition to the equilibrium bainite. Usual austempering times vary from 1 to $4 \mathrm{~h}$, [29].

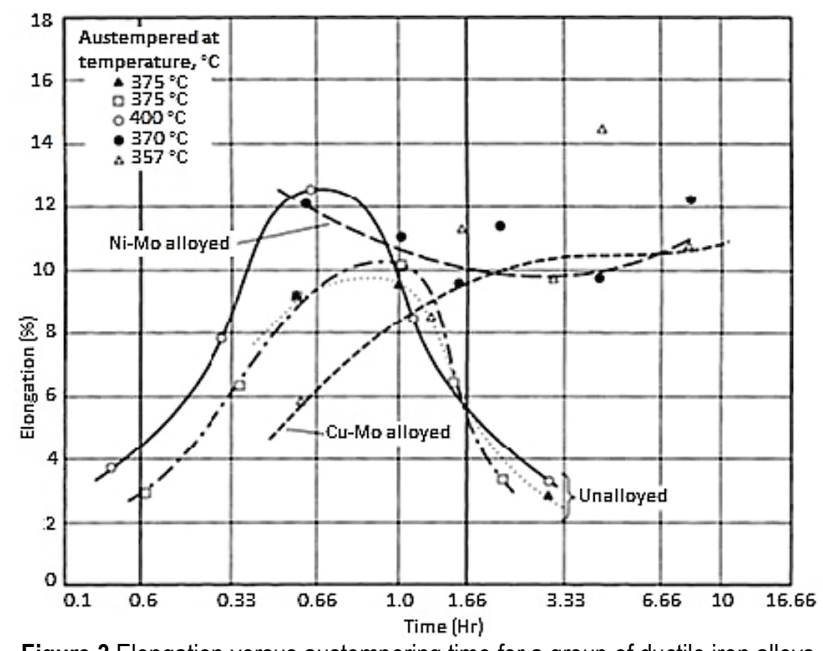

Figure 3 Elongation versus austempering time for a group of ductile iron alloys [29]

\subsection{Molybdenum Effect}

Although molybdenum is often used as an alloying element in ductile iron, its effect on the final mechanical properties of ADI has not been studied. Some works have been done on alloys with molybdenum in its chemical composition, however its effect has not been deeply studied, [24, 30-34]. To vaguely understand the effects that molybdenum has on the properties of ADI, comparison of mechanical properties for alloys with and without molybdenum must be made.

O. Eric et al. in their work [24] have studied three ductile iron samples with almost identical chemical composition with slight variations in molybdenum content $(0.278 \%, 0.296 \%$ and $0.299 \%$ Mo). They produced ADI from these samples using different austempering temperatures and holding times. Obtained results, which are average of five tests, show that for samples austempered at $320{ }^{\circ} \mathrm{C}$, toughness abruply increased to a maximum of $115 \mathrm{~kJ}$ after $2.5 \mathrm{~h}$ of austempering. The highest impact energy fits to ductile fracture and the volume fraction of retained austenite is 
also highest at this point (25 \%). With longer austempering time, toughness decreases to values between $85 \mathrm{~kJ}$ and $90 \mathrm{~kJ}$. Samples austempered at $400{ }^{\circ} \mathrm{C}$ have very low impact energy between $10 \mathrm{~kJ}$ and $12 \mathrm{~kJ}$, for 0.5 to $5 \mathrm{~h}$ of austempering. Results are shown in Fig. 4.
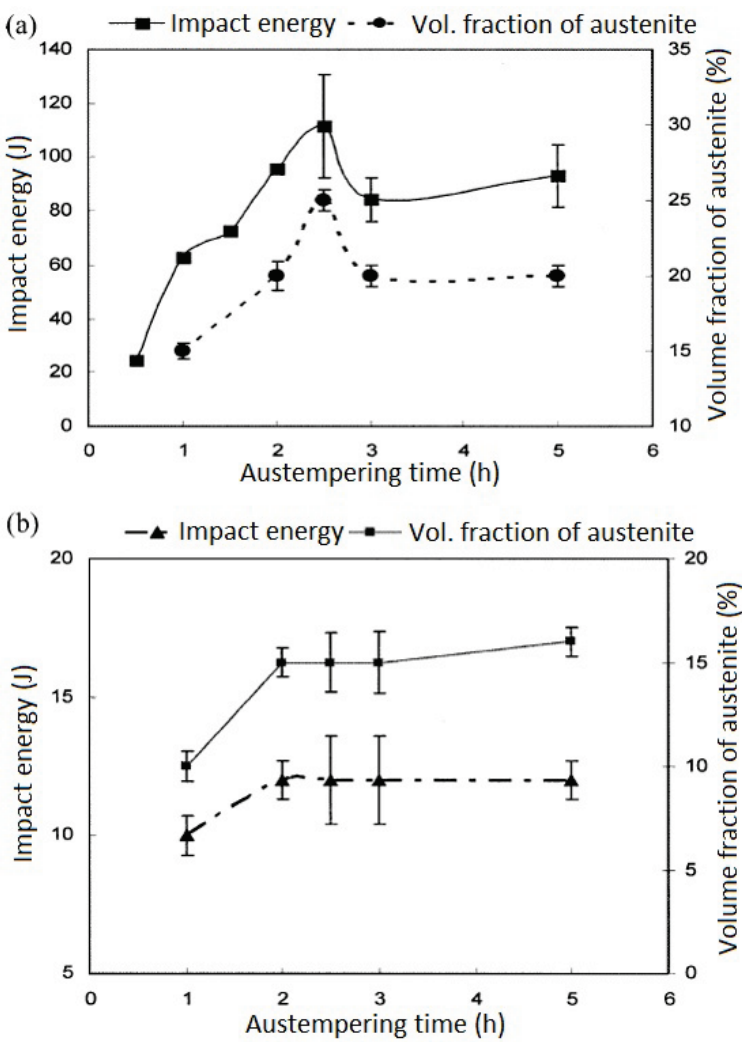

Figure 4 The effect of austempering time on impact energy and volume fraction of retained austenite at $320^{\circ} \mathrm{C}$ (a) and $400{ }^{\circ} \mathrm{C}$ (b) [24]

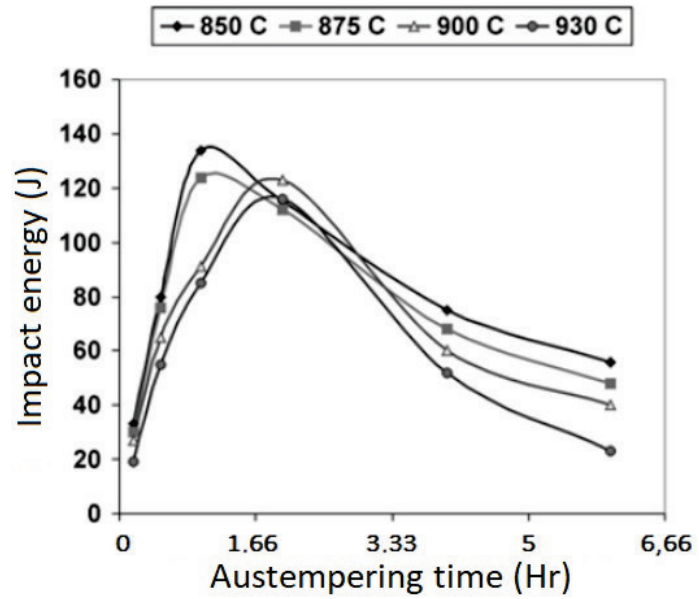

Figure 5 Variation of impact energy with austempering time after austenitising at $850,875,900$ and $930{ }^{\circ} \mathrm{C}$ for $120 \mathrm{~min}$ [31]

For austempering ductile iron with $0.25 \%$ of molybdenum on different austenitising temperatures for 2 $\mathrm{h}$ and austempering at $350{ }^{\circ} \mathrm{C}$ for different holding times, this can result in a variation in toughness, [31]. As seen in Fig. 5, lower austenitising temperatures and shorter austempering times result in the highest impact energy. The drop in impact energy at an austenitizing temperature of $930{ }^{\circ} \mathrm{C}$ appeared to be caused by a reduction in austenite-carbon content as a result of carbide precipitation and can be linked with the molybdenum content in the chemical composition. Also, difficulty in achieving high ductility in molybdenum alloyed ADI can be linked with the transformation of retained austenite to martensite when cooling to room temperature, [32].

Unlike copper, molybdenum atoms segregate in the cell boundary and form carbides there. The molybdenumcontaining carbides can hardly dissolve in the austenitizing process, so following the austenitizing treatment, the microstructure of the austenite matrix is not uniform and the carbon content in the matrix may be lower in specimens with higher molybdenum content, [33]. Fig. 6 shows that volume fraction of retained austenite decreases continuously with the increase of molybdenum content.

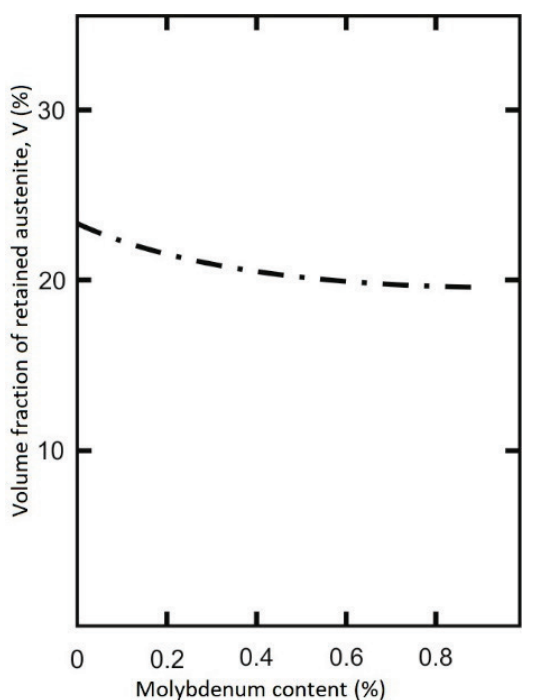

Figure 6 Volume fraction of retained austenite, $\mathrm{Vr}$, vs. molybdenum content of ADI [33]

Comparing all those results with results from other studies which have used ADI without molybdenum, [7, 8, $35,36]$, it can be seen that samples with molybdenum, [24, 30-34], content in its chemical composition have less volume fraction of retained austenite and lower toughness than the samples without molybdenum in its chemical composition.

\subsection{Manganese Effect}

Similar to molybdenum, manganese effect on mechanical properties of ADI has not been deeply studied. Although manganese is often found in chemical composition of ductile irons, solely its effect is yet to be determined. Few works have been conducted on ductile irons with manganese in its chemical composition, [37, $38,39]$, so some conclusions can be deduced from those results. In most articles, selection of ductile iron chemical composition is based on the traditional low-manganese concept because of its strong segregation to intercellular regions. Also it delays Stage I reaction leading to the closure of the processing window meant for the production of ADI and optimal mechanical properties, [39].

B. Y. Lin et al. in their work [37] have studied four samples of ductile iron, each containing $0.4 \% \mathrm{Mn}, 1 \%$ $\mathrm{Cu}, 1.5 \% \mathrm{Ni}$ and $0.4 \%$ Mo separately. All samples undertook the same heat treatment parameters, 
austenitizing at $900{ }^{\circ} \mathrm{C}$ for $1 \mathrm{~h}$ then austempering at 400 ${ }^{\circ} \mathrm{C}$ for $50 \mathrm{~min}$. For each sample, electrical resistivity, impact energy and hardness have been measured. Figs. 7 and 8 show the Rockwell hardness and impact strength variations for those heat treatment conditions relating to $\mathrm{Mn}, \mathrm{Cu}, \mathrm{Ni}$ and Mo alloyed ductile irons.

It is shown that the hardness ADI have no significant difference and is a little higher than that of as-cast samples. The impact strength of ADI samples is nearly three times greater than that of the as-cast samples, [37]. All of these results can be explained with the high austempering temperature of $400{ }^{\circ} \mathrm{C}$ which gives ADIs with lower hardness and strength but higher ductility and impact strength.

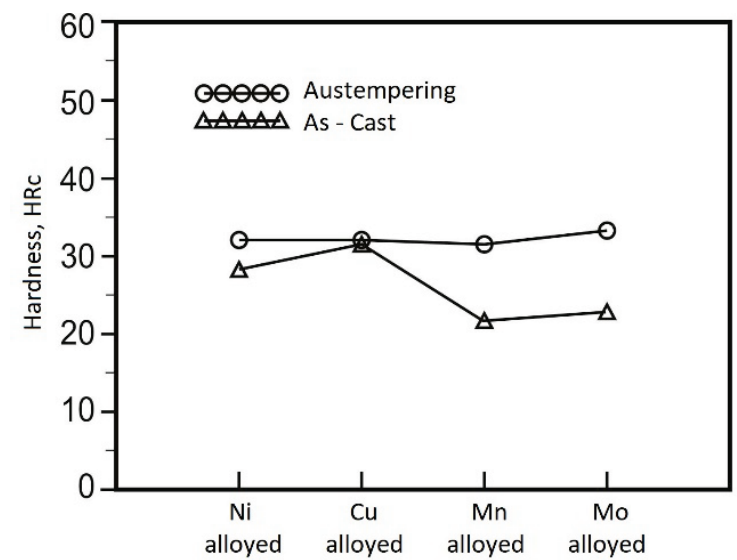

Figure 7 The effect of $\mathrm{Ni}, \mathrm{Cu}, \mathrm{Mn}$ and $\mathrm{Mo}$ alloyed ductile irons on Rockwell hardness [37]

Mechanical properties for those four alloyed ductile irons are directly related to microstructure of those samples. Samples alloyed with $\mathrm{Ni}, \mathrm{Cu}$ and $\mathrm{Mn}$ have homogenous matrix, so the impact values of these three alloyed ductile irons are very similar. Mo retards bainite reaction and causes the micro shrinkage porosity in those regions which leads to lowest impact strength of those four samples.

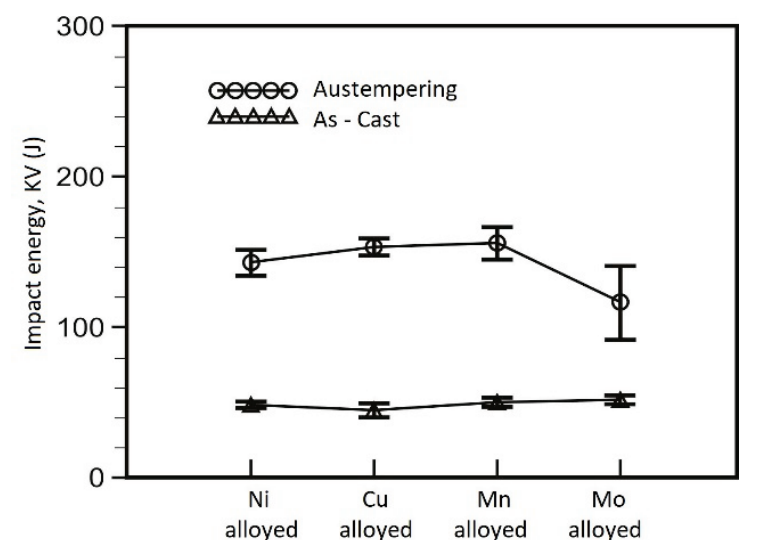

Figure 8 The effect of $\mathrm{Ni}, \mathrm{Cu}, \mathrm{Mn}$ and $\mathrm{Mo}$ alloyed ductile irons on impact strength [37]

Comparing results of studies which used ADI with manganese with those without manganese it can be concluded that manganese improves hardenability but decreases ductility and elongation. When copper and manganese alloyed ductile irons are used, results show absence of usual manganese segregation. This can be explained by the copper and manganese opposite segregation behaviour, [38, 39]. Copper and silicon segregate toward the graphite nodules, while manganese segregates in the intercellular regions. When copper and manganese are used in equal proportions, it is expected that the negative segregation of copper will neutralize the positive segregation of manganese. Also, higher manganese amount (up to about $1.00 \%$ ) decreases the eutectoid transformation temperature, [39].

\section{CONCLUSION}

The ADI materials when compared to ductile irons in as-cast condition have higher impact energies and the transition curves for ADIs are shifted towards lower temperatures. ADIs with lower ausferritic microstructure exhibit better fracture toughness than those with upper ausferritic microstructure. The optimum austempering temperature for maximum fracture toughness decreases with increasing austenitizing temperature. Strength, elongation, impact energy and hardness are strongly dependant on the amounts of ausferrite ferrite and retained austenite, as well as their morphology. Morphology is influenced by alloying elements, hence the correlation between mechanical properties and austempering parameters is very complex and characteristic for any given ADI material. Alloying ductile iron with copper and nickel produces more ductile grades of ADI, while alloying only with copper produces higher strength ADI grades. The processing window for ADI alloyed only with copper is between 107 and 202 min, while for ADI alloyed with both copper and nickel it is between 114 and $213 \mathrm{~min}$. It is shown that retained austenite content increases with the copper content but decreases with the molybdenum content and when that happens the fracture mode changes from ductile to brittle.

Copper and molybdenum additions play an effective role in the formation of ausferrite structure as well as increase tensile strength and hardenability. Manganese content is generally restricted to $0.25 \%$ because of its segregation tendency in the intercellular regions. However, the potent alloying interaction suggests that smaller additions of multiple alloying elements are more effective in improving austemperability than large additions of single alloying elements. It should be pointed out that mechanical properties of ADIs are only achieved through the correct microstructure, which is in turn a function of the chemical composition and austempering parameters, and that the microstructure needs to be closely controlled.

Preview of results from aforementioned studies, [8], $[24,30,31,34-37]$, is shown in the Appendix 1. In the table in Appendix 1 chemical compositions, heat treatment parameters and obtained mechanical properties are given. Some studies have been excluded from the table, [7, 32, 33, 38, 39], because emphasise is given on volume fraction of retained austenite and not mechanical properties although conclusions can be drawn from data of retained austenite.

Future work should be orientated towards optimization of the austempering processes for given alloying elements which should result in mathematical models defining behaviour of mechanical properties, depending on different amounts of each alloying element. 


\section{Acknowledgements}

This work has been fully supported by the Croatian Science Foundation under the project 5371. Authors express special thanks to Ph.D. David Kennedy for his help with proofreading of the English translation.

\section{REFERENCES}

[1] Behera, G. \& Sohala, S. R. (2012). Effect of copper on the properties of austempered ductile iron castings. Bachelor thesis. Department of Metallurgical and Materials Engineering, National Institute of Technology, Rourkela, India.

[2] Sidjanin, L. \& Smallman, R. E. (1992). Mater. Sci. Tech. Lond. 8, 1095. https://doi.org/10.1179/mst.1992.8.12.1095

[3] Elliot, R. (1997). Heat Treatments of Metals. 3, 55.

[4] Chandler H. (1995). Heat treaters guide: practices and procedures for irons and steels. ASTM International, $2 \mathrm{Sub}$ edition (December 1995).

[5] Živković, D., Gabrić, I., Dadić, Z., Čatipović, N., \& Vrljičak, I. (2015). Analysis of austempering treatment parameters on properties of ductile iron EN-GJS-400. Zbornik radova $=$ Proceedings, Hrvatsko društvo za strojarske tehnologije, MTSM 2015, Split.

[6] Harding, R. A. (2007). Kovove Mater., 45, p. 1.

[7] Sidjanin, L., Smallman, R. E., \& Young, J. M. (1994). Electron microstructure and mechanical properties of silicon and aluminium ductile irons. Acta Metallurgica et Materialia 42(9), 3149-3156. https://doi.org/10.1016/0956-7151(94)90412-X

[8] Rajnovic, D., Eric, O., \& Sidjanin, L. (2012). The standard processing window of alloyed ADI materials. Kovove Mater., 50, 199-208. https://doi.org/10.4149/km_2012_3_199

[9] Bartra, U., Ray, S., \& Prabhakar, S. R. (2004). The influence of nickel and copper on the austempering of ductile iron. Journal of Materials Engineering and Performance, 13(1), 64-68. https://doi.org/10.1361/10599490417515

[10] Chang, C. H. \& Shih, T. S. (1994). Trans. Jpn. Foundrymen Soc., 13, pp. 56.

[11] Thomson, R. C. (2000). Mater. Sci. Tech. - Lond., 16, pp. 1412.

[12] Bayati, H. \& Elliott, R. (2000). Mater. Sci. Forum, 329, pp. 73. https://doi.org/10.4028/www.scientidic.net/MSF.329-330.73

[13] Zahiri, S. H., Davies, C. H. J., \& Pereloma, E. V. (2003). Mater. Sci. Tech. - Lond., pp. 1761.

[14] Eric, O., Rajnovic, D., Zec, S., Sidjanin, L., \& Jovanovic, M. T. (2006). Mater. Charact., 57, pp. 211, https://doi.org/10.1016/j.matchar.2006.01.014

[15] Bayati, H. \& Elliott, R. (1999). Int. J. Cast Metal Res., 11, pp. 413. https://doi.org/10.1080/13640461.1999.11819309

[16] Dorn, T., Keough, J. R., Schroeder, T., \& Thoma T. (2003). Proceedings of the Keith D. Millis Symposium. Ed.: Wood J. N., Hilton Head, South Carolina, USA, Ductile Iron Society and AFS, pp 1 . https://doi.org/10.1016/j.msea.2004.04.076

[17] Alabi, A. G. F. \& Aluko, F. I. (2013). Production of Austempered Ductile Ironwith Optimum Sulphur Level for Effective mechanical Properties. The International journal of Engineeringand Science (IJES), 2(12), 67-71.

[18] Keough, J. R. \& Hayrynen, K. L. (2010). Designing with Austempered Ductile Iron (ADI). AFS Proceedings 2010, Schaumburg, IL, USA, American Foundrymen Society, 115.

[19] Heat Treater's Guide: Practices and procedures for Ironsand Steels, ASM International, Harry Chandlered., Materials Park, Ohio, Second Edition, 1995, 824-835.
[20] Tun, T., Lwin K. T. (2009). Optimizing the microstructure and mechanical properties of ADI for automobile differential gear. Journal of metals, materials and minerals, $18(2), 199-205$.

[21] Singh, V. (2007). Physical Metallurgy, First Edition (1999), Reprint 2007, Standard Publishers Distributers, 1705-B, NaiSarak, New Delhi-110006.

[22] Čatipović, N., Živković, D., Dadić, Z., Sučić, A., \& Ljumović, P. (2015). Utjecaj izotermičke temperature i vremena držanja na mikrostrukturu i tvrdoću izotermičkog žilavog lijeva. MTSM 2015, Split.

[23] Yang, J. \& Putatunda, S. K. (2004). Improvement in strength and toughness of austempered ductile cast iron by a novel two-step austempering process. Mater. Des., 25, 219-230. https://doi.org/10.1016/j.matdes.2003.09.021

[24] Eric, O., Sidjanin, L., Miskovic, Z., Zec, S., \& Jovanovic, M. T. (2004). Microstructure and toughness of $\mathrm{Cu}, \mathrm{Ni}, \mathrm{Mo}$ austempered ductile iron. Mater. Lett. 58, 2707-2711. https://doi.org/10.1016/j.matlet.2004.02.041

[25] Kovacs, B. V. (1990). Austempered Ductile Iron: Fact and Fiction. Mod. Cast., 38-41.

[26] Mon, I. C. \& Tierean, M. H. (2015). A review on tests of austempered ductile iron welding. Bulletin of the Transilvania University of Brasov, 8(57)1, 59-66

[27] El-Kashif, E. \& Morsy, M. A. (2011). Welding of Austempered Ductile Cast Iron. New York Science Journal, $4(4), 21-27$

[28] Sun, D., Zhou, Z., \& Cao, H. (1996). Effect of Si, Al and Bi on Structure and Properties of As-welded and Austempered Ductile Iron Weld Metals during Gas Welding. J. Mater. Sci. Technol., 12, 347-352.

[29] ASM Metals Handbook Volume 04 - Heat Treatment: Heat Treating of Ductile Irons, p. 1498.

[30] Eric, O., Rajnovic, D., Sidnjanin, L., Zec, S., \& Jovanovic, M. T. (2005). An austempering study on ductile iron alloyed with copper. J. Serb. Chem. Soc., 70, 1015-1022. https://doi.org/10.2298/JSC050715E

[31] Radulovic, B., Bosnjak, B., Harding, R., Pop-Tonev, K., \& Asanovic, V. (2000). The influence of austenitising temperature on the microstructure and mechanical properties of low-alloyed Ni-Mo-Cu austempered ductile iron. Mater. Tehnol. 34(5), 207-212.

[32] Bosnjak, B. \& Radulovic, B. (2004). Effect of austenitising temperature on austempering kinetics of $\mathrm{Ni}-\mathrm{Mo}$ alloyed ductile iron. MTAEC9, 38(6), 307-312.

[33] Mi, Yan. (1995). Effect of $\mathrm{Cu}, \mathrm{Mo}, \mathrm{Si}$ on the content of retained austenite of austempered ductile iron. Scripta Metallurgica et Materialia, 32(9), 1313-1317. https://doi.org/10.1016/0956-716X(95)00163-P

[34] Kim, Y. J., Shin, H., Park, H., \& Lim, J. D. (2008). Investigation into mechanical properties of austempered ductile cast iron (ADI) in accordance with austempering temperature. Materials Letters, 62, 357-360. https://doi.org/10.1016/j.matlet.2007.05.028

[35] Sidjanin, L., Rajnovic, D., Eric, O., \& Smallman, R. E. (2010). Austempering study of unalloyed and alloyed ductile irons. Materials Science and Technology, 5(26), 567-571. https://doi.org/10.1179/174328409X407524

[36] Sharma, A., Singh, K. K., \& Gupta, G. K. (2016). Study on the Effects of Austempering Variables and Copper Addition on Mechanical Properties of Austempered Ductile Iron. AIMTDR, India.

[37] Lin, B.Y., Chen, E. T., \& Lei, T. S. (1995). The effect of alloy elements on the microstructure and properties of austempered ductile irons. Scripta Metallurgica et Materialia, 32(9), 1363-1367. https://doi.org/10.1016/0956-716X(95)00172-R

[38] Bahmani, M., Elliott, R., \& Varahram, N. (1997). The austempering kinetics and mechanical properties of an 
austempered $\mathrm{Cu}-\mathrm{Ni}-\mathrm{Mo}-\mathrm{Mn}$ alloyed ductile iron. Journal of Materials Science, 32, 4783-4791.

https://doi.org/10.1023/A:1018687115732

[39] Dasgupta, R. K., Mondal, D. K., \& Chakrabarti, A. K. (2013). Evolution of Microstructures During Austempering of Ductile Irons Alloyed with Manganese and Copper. The Minerals, Metals \& Materials Society and ASM International, 44A, 1376-1387. https://doi.org/10.1007/s11661-012-1502-0

\section{Contact information}

Nikša ČATIPOVIĆ, mag. ing. mech.

Faculty of Electrical Engineering, Mechanical Engineering and Naval Architecture, University of Split

Ruđera Boškovića 32, 21000 Split, Republic of Croatia niksa.catipovic@fesb.hr

Dražen ŽıVKOVIĆ, prof. dr. sc.

Faculty of Electrical Engineering, Mechanical Engineering and Naval Architecture, University of Split

RuđeraBoškovića 32, 21000 Split, Republic of Croatia drazen.zivkovic@fesb.hr

Zvonimir DADIĆ, mag. ing. mech.

Faculty of Electrical Engineering, Mechanical Engineering and Naval Architecture, University of Split

Ruđera Boškovića 32, 21000 Split, Republic of Croatia

zvonimir.dadic@fesb.hr

\section{APPENDIX 1:}

Table 1 Obtained mechanical properties from studies [8,24,30,31,34-37] depending on chemical compositions of used ductile irons and heat treatment parameters

\begin{tabular}{|c|c|c|c|c|c|c|c|c|c|c|c|c|c|c|c|c|c|c|c|c|c|}
\hline \multirow{2}{*}{ Ref. } & \multicolumn{13}{|c|}{ Chemical composition of ductile iron samples used for austempering, $(\%)$} & \multicolumn{4}{|c|}{ Heat treatment parameters } & \multicolumn{4}{|c|}{ ADI mechanical properties } \\
\hline & $\mathrm{C}$ & $\mathrm{Si}$ & $\mathrm{s}$ & $\mathrm{P}$ & $\mathrm{Mn}$ & Mo & $\mathrm{Cr}$ & $\mathrm{Ni}$ & $\mathrm{Cu}$ & $\mathrm{Mg}$ & $\mathrm{B}$ & W & $\mathrm{Al}$ & $T_{\mathrm{a}},\left({ }^{\circ} \mathrm{C}\right)$ & $\tau_{\mathrm{a}},(\mathrm{h})$ & $T_{\mathrm{iz},}\left({ }^{\circ} \mathrm{C}\right)$ & $\tau_{\mathrm{i}, 2}(\mathrm{~h})$ & $H$ & $R m,(\mathrm{MPa})$ & $K v,(\mathrm{~J})$ & $E,(\%)$ \\
\hline \multirow{30}{*}{8} & \multirow{16}{*}{3,640} & \multirow{16}{*}{2,490} & \multirow{15}{*}{ | 0,014} & \multirow{15}{*}{0,014} & \multirow{15}{*}{0,300} & \multirow{15}{*}{1} & \multirow{15}{*}{1} & \multirow{16}{*}{1} & \multirow{15}{*}{0,460} & \multirow{15}{*}{0,066} & \multirow{16}{*}{1} & & & & & & 1,0 & $452 \mathrm{HV} 10$ & 1427 & 52,6 & 1,4 \\
\hline & & & & & & & & & & & & & & & & & 2,0 & $451 \mathrm{HV} 10$ & 1428 & 59,7 & 3,4 \\
\hline & & & & & & & & & & & & & & & & 300 & 3,0 & 378 HV10 & 1445 & 76,9 & 3,7 \\
\hline & & & & & & & & & & & & & & & & & 4,0 & 406 HV10 & 1481 & 71,5 & 3,1 \\
\hline & & & & & & & & & & & & & & & & & 6,0 & $436 \mathrm{HV} 10$ & 1412 & 69,4 & 2,7 \\
\hline & & & & & & & & & & & & & & & & & 1,0 & $402 \mathrm{HV} 10$ & 1158 & 85,6 & 4,7 \\
\hline & & & & & & & & & & & & & & & & & 2,0 & 373 HV10 & 1112 & 106,1 & 7,9 \\
\hline & & & & & & & & & & & & 1 & 1 & 900 & 2,0 & 350 & 3,0 & $350 \mathrm{HV} 10$ & 1109 & 105,1 & 7,1 \\
\hline & & & & & & & & & & & & & & & & & 4,0 & 391 HV10 & 1205 & 100,8 & 5,9 \\
\hline & & & & & & & & & & & & & & & & & 6,0 & $420 \mathrm{HV} 10$ & 1160 & 91,6 & 5,3 \\
\hline & & & & & & & & & & & & & & & & & 1,0 & 345 HV10 & 977 & 86,3 & 6,3 \\
\hline & & & & & & & & & & & & & & & & & 2,0 & 344 HV10 & 984 & 89,4 & 7,1 \\
\hline & & & & & & & & & & & & & & & & 400 & 3,0 & 327 HV10 & 987 & 56,5 & 6,2 \\
\hline & & & & & & & & & & & & & & & & & 4,0 & 332 HV10 & 1007 & 23,0 & 4,5 \\
\hline & & & & & & & & & & & & & & & & & 6,0 & 364 HV10 & 1019 & 20,4 & 2,0 \\
\hline & & & & & & & & & & & & & & & & & 1,0 & 454 HV10 & 1390 & 52,6 & 3,5 \\
\hline & & & & & & & & & & & & & & & & & 2,0 & 414 HV10 & 1354 & 59,7 & 4,5 \\
\hline & & & & & & & & & & & & & & & & 300 & 3,0 & 384 HV10 & 1396 & 76,9 & 5,5 \\
\hline & & & & & & & & & & & & & & & & & 4,0 & $424 \mathrm{HV} 10$ & 1375 & 71,5 & 5,6 \\
\hline & & & & & & & & & & & & & & & & & 6,0 & 462 HV10 & 1325 & 69,4 & 3,4 \\
\hline & & & & & & & & & & & & & & & & & 1,0 & $415 \mathrm{HV} 10$ & 1111 & 46,1 & 5,4 \\
\hline & & & & & & & & & & & & & & & & & 2,0 & 383 HV10 & 1109 & 90,2 & 10,0 \\
\hline & 3,480 & 2,190 & 0,012 & 0,020 & 0,260 & 1 & 1 & 1,510 & 1,570 & 0,060 & 1 & 1 & 1 & 900 & 2,0 & 350 & 3,0 & 308 HV10 & 1070 & 122,1 & 11,1 \\
\hline & & & & & & & & & & & & & & & & & 4,0 & 351 HV10 & 1043 & 106,1 & 10,1 \\
\hline & & & & & & & & & & & & & & & & & 6,0 & 380 HV10 & 1042 & 50,3 & 6,1 \\
\hline & & & & & & & & & & & & & & & & & 1,0 & 308 HV10 & 973 & 100,2 & 10,6 \\
\hline & & & & & & & & & & & & & & & & & 2,0 & 322 HV10 & 989 & 94,3 & 10,9 \\
\hline & & & & & & & & & & & & & & & & 400 & 3,0 & $344 \mathrm{HV} 10$ & 950 & 82,5 & 7,7 \\
\hline & & & & & & & & & & & & & & & & & 4,0 & $361 \mathrm{HV} 10$ & 986 & 78,4 & 7,1 \\
\hline & & & & & & & & & & & & & & & & & 6,0 & 438 HV10 & 959 & 57,8 & 5,6 \\
\hline & & & & & & & & & & & & & & & & & 0,5 & 1 & 1 & 25 & 1 \\
\hline & & & & & & & & & & & & & & & & & 1,0 & 1 & 1 & 63 & 1 \\
\hline & & & & & & & & & & & & & & & & & 1,5 & 1 & 1 & 71 & 1 \\
\hline & & & & & & & & & & & & & & & & 320 & 2,0 & 1 & 1 & 95 & 1 \\
\hline & & & & & & & & & & & & & & & & & 2,5 & 1 & 1 & 115 & 1 \\
\hline & & & & & & & & & & & & & & & & & 3,0 & 1 & 1 & 80 & 1 \\
\hline 24 & 3,500 & 2,500 & 0,008 & 0,042 & 0,300 & 0,296 & 0,050 & 0,950 & 0,800 & 0,047 & 0,0004 & 0,039 & 0,030 & 860 & 1,0 & & 5,0 & 1 & 1 & 90 & 1 \\
\hline & & & & & & & & & & & & & & & & & 1,0 & 1 & 1 & 10 & 1 \\
\hline & & & & & & & & & & & & & & & & & 2,0 & 1 & 1 & 12 & 1 \\
\hline & & & & & & & & & & & & & & & & 400 & 2,5 & 1 & 1 & 12 & 1 \\
\hline & & & & & & & & & & & & & & & & & 3,0 & 1 & 1 & 12 & 1 \\
\hline & & & & & & & & & & & & & & & & & 5,0 & 1 & 1 & 12 & 1 \\
\hline
\end{tabular}


Table 1 Obtained mechanical properties from studies [8, 24, 30, 31, 34-37] depending on chemical compositions of used ductile irons and heat treatment parameters (continuation)

\begin{tabular}{|c|c|c|c|c|c|c|c|c|c|c|c|c|c|c|c|c|c|c|c|c|c|}
\hline \multirow{2}{*}{ Ref. } & \multicolumn{13}{|c|}{ Chemical composition of ductile iron samples used for austempering, (\%) } & \multicolumn{4}{|c|}{ Heat treatment parameters } & \multicolumn{4}{|c|}{ ADI mechanical properties } \\
\hline & $\mathrm{C}$ & $\mathrm{Si}$ & $\mathrm{S}$ & $\mathrm{P}$ & $\mathrm{Mn}$ & Mo & $\mathrm{Cr}$ & $\mathrm{Ni}$ & $\mathrm{Cu}$ & $\mathrm{Mg}$ & $B$ & \begin{tabular}{l|l} 
W \\
\end{tabular} & $\mathrm{Al}$ & $T_{\mathrm{a}},\left({ }^{\circ} \mathrm{C}\right)$ & $\tau_{\mathrm{a}},(\mathrm{h})$ & $T_{\mathrm{iz}},\left({ }^{\circ} \mathrm{C}\right)$ & $\tau_{\mathrm{iz}},(\mathrm{h})$ & $H$ & $R m,(\mathrm{MPa})$ & $K v,(\mathrm{~J})$ & $E,(\%)$ \\
\hline & & & & & & & & & & & & & & & & & 1,0 & 1 & 1440 & 32 & 0,5 \\
\hline & & & & & & & & & & & & & & & & 300 & 2,0 & 1 & 1435 & 60 & 3,5 \\
\hline & & & & & & & & & & & & & & & & 300 & 3,0 & 1 & 1450 & 62 & 3,7 \\
\hline & & & & & & & & & & & & & & & & & 4,0 & 1 & 1455 & 30 & 3,0 \\
\hline & & & & & & & & & & & & & & & & & 1,0 & 1 & 1150 & 70 & 5,7 \\
\hline & & & & & & & & & & & & & & & & & 2,0 & 1 & 1100 & 105 & 8,0 \\
\hline 30 & 3,600 & 2,500 & 0,014 & 0,014 & 0,280 & 1 & 0,040 & 1 & 0,450 & 0,066 & 1 & 1 & 1 & 900 & 2,0 & 350 & 3,0 & 1 & 1100 & 92 & 7,2 \\
\hline & & & & & & & & & & & & & & & & & 4,0 & 1 & 1200 & 75 & 6,0 \\
\hline & & & & & & & & & & & & & & & & & 1,0 & 1 & 975 & 73 & 5,0 \\
\hline & & & & & & & & & & & & & & & & 400 & 2,0 & 1 & 980 & 87 & 7,0 \\
\hline & & & & & & & & & & & & & & & & 400 & 3,0 & 1 & 985 & 45 & 6,2 \\
\hline & & & & & & & & & & & & & & & & & 4,0 & 1 & 1000 & 24 & 4,5 \\
\hline & & & & & & & & & & & & & & & & & 0,16 & 1 & 1 & 34 & 1 \\
\hline & & & & & & & & & & & & & & & & & 0,50 & 1 & 1 & 80 & 1 \\
\hline & & & & & & & & & & & & & & & & & 1,00 & 1 & 1 & 135 & 1 \\
\hline & & & & & & & & & & & & & & 850 & & & 2,00 & 1 & 1 & 115 & 1 \\
\hline & & & & & & & & & & & & & & & & & 4,00 & 1 & 1 & 78 & 1 \\
\hline & & & & & & & & & & & & & & & & & 6,00 & 1 & 1 & 58 & 1 \\
\hline & & & & & & & & & & & & & & & & & 0,16 & 1 & 1 & 30 & 1 \\
\hline & & & & & & & & & & & & & & & & & 0,50 & 1 & 1 & 78 & 1 \\
\hline & & & & & & & & & & & & & & & & & 1,00 & 1 & 1 & 125 & 1 \\
\hline & & & & & & & & & & & & & & $8 / 5$ & & & 2,00 & 1 & 1 & 110 & 1 \\
\hline & & & & & & & & & & & & & & & & & 4,00 & 1 & 1 & 70 & 1 \\
\hline & & & & & & & & & & & & & & & & & 6,00 & 1 & 1 & 50 & 1 \\
\hline 31 & 3,140 & 2,670 & 0,003 & 0,023 & 0,070 & 0,250 & 0,120 & 0,800 & 0,300 & 1 & 1 & 1 & 1 & & 2,0 & 350 & 0,16 & 1 & 1 & 27 & 1 \\
\hline & & & & & & & & & & & & & & & & & 0,50 & 1 & 1 & 65 & 1 \\
\hline & & & & & & & & & & & & & & & & & 1,00 & 1 & 1 & 90 & 1 \\
\hline & & & & & & & & & & & & & & 900 & & & 2,00 & 1 & 1 & 125 & 1 \\
\hline & & & & & & & & & & & & & & & & & 4,00 & 1 & 1 & 60 & 1 \\
\hline & & & & & & & & & & & & & & & & & 6,00 & 1 & 1 & 40 & 1 \\
\hline & & & & & & & & & & & & & & & & & 0,16 & 1 & 1 & 20 & 1 \\
\hline & & & & & & & & & & & & & & & & & 0,50 & 1 & 1 & 55 & 1 \\
\hline & & & & & & & & & & & & & & & & & 1,00 & 1 & 1 & 85 & 1 \\
\hline & & & & & & & & & & & & & & 930 & & & 2,00 & 1 & 1 & 114 & 1 \\
\hline & & & & & & & & & & & & & & & & & 4,00 & 1 & 1 & 54 & 1 \\
\hline & & & & & & & & & & & & & & & & & 6,00 & 1 & 1 & 22 & 1 \\
\hline & & & & & & & & & & & & & & & & 350 & & $341 \mathrm{HB}$ & 1125 & 101,9 & 8,0 \\
\hline 34 & 3520 & 2670 & 0006 & 030 & 0200 & 0250 & 1 & 1 & 0870 & 0032 & 1 & 1 & 1 & 010 & 15 & 370 & 15 & $336 \mathrm{HB}$ & 1104 & 116,5 & 8,0 \\
\hline 34 & 3,520 & $2,6 / 0$ & 0,006 & 0,030 & 0,290 & 0,250 & 1 & 1 & $0,8 / 0$ & 0,032 & 1 & 1 & 1 & 910 & 1,5 & 390 & 1,5 & $299 \mathrm{HB}$ & 965 & 128,9 & 9,0 \\
\hline & & & & & & & & & & & & & & & & 410 & & $292 \mathrm{HB}$ & 967 & 136,2 & 10,0 \\
\hline & & & & & & & & & & & & & & & & & 1,0 & 1 & 1140 & 95 & 6,5 \\
\hline & & & & & & & & & & & & & & & & & 2,0 & 1 & 1150 & 80 & 5,5 \\
\hline & 3,800 & 2,900 & 0,006 & 0,020 & 0,080 & 1 & 1 & 1 & 1 & 0,032 & 1 & 1 & 1 & & 1.5 & & 3,0 & 1 & 1160 & 55 & 4.0 \\
\hline & & & & & & & & & & & & & & & & & 4,0 & 1 & 1 & 1 & 1 \\
\hline & & & & & & & & & & & & & & & & & 6,0 & 1 & 1 & 1 & 1 \\
\hline & & & & & & & & & & & & & & & & & 1,0 & 1 & 1150 & 85 & 4,5 \\
\hline & & & & & & & & & & & & & & & & & 2,0 & 1 & 1110 & 105 & 8,0 \\
\hline 35 & 3,600 & 2,500 & 0,014 & 0,014 & 0,280 & 1 & 1 & 1 & 0,470 & 0,066 & 1 & 1 & 1 & 900 & 2,0 & 350 & 3,0 & 1 & 1100 & 105 & 7,0 \\
\hline & & & & & & & & & & & & & & & & & 4,0 & 1 & 1200 & 100 & 6,0 \\
\hline & & & & & & & & & & & & & & & & & 6,0 & 1 & 1180 & 90 & 5,5 \\
\hline & & & & & & & & & & & & & & & & & 1,0 & 1 & 1100 & 45 & 5,5 \\
\hline & & & & & & & & & & & & & & & & & 2,0 & 1 & 1100 & 90 & 10,0 \\
\hline & 3,070 & 2,150 & 0,010 & 0,020 & 0,260 & 1 & 1 & 1,500 & 1,600 & 0,043 & 1 & 1 & 1 & & 2,0 & & 3,0 & 1 & 1080 & 120 & 11,0 \\
\hline & & & & & & & & & & & & & & & & & 4,0 & 1 & 1020 & 105 & 10,0 \\
\hline & & & & & & & & & & & & & & & & & 6,0 & 1 & 1020 & 50 & 6,0 \\
\hline & & & & & & & & & & & & & & & & 300 & 1,0 & $308 \mathrm{HB}$ & 998 & 28 & 3,3 \\
\hline & 3600 & 250 & 0150 & 1 & 0250 & 1 & 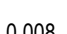 & 0 & 0450 & 0107 & 1 & 1 & 1 & 950 & 20 & 300 & 1,5 & $302 \mathrm{HB}$ & 1022 & 31 & 3,5 \\
\hline & 3,600 & 2,550 & 0,150 & 1 & 0,250 & 1 & 0,008 & 0,005 & 0,450 & 0,101 & 1 & 1 & 1 & 950 & 2,0 & & 1,0 & $285 \mathrm{HB}$ & 914 & 32 & 5,4 \\
\hline 36 & & & & & & & & & & & & & & & & 360 & 1,5 & $271 \mathrm{HB}$ & 908 & 37 & 5,6 \\
\hline 36 & & & & & & & & & & & & & & & & & 1,0 & $219 \mathrm{HB}$ & 948 & 12 & 4,1 \\
\hline & 3670 & & 0150 & 1 & 0238 & 1 & 0072 & 0008 & 0030 & 030 & & & & & & 300 & 1,5 & $198 \mathrm{HB}$ & 915 & 16 & 4,6 \\
\hline & 3,670 & 2,640 & 0,150 & 1 & 0,238 & 1 & 0,072 & 0,008 & 0,030 & 0,030 & 1 & 1 & 1 & 950 & 2,0 & & 1,0 & $201 \mathrm{HB}$ & 859 & 14 & 6,2 \\
\hline & & & & & & & & & & & & & & & & 360 & 1,5 & $184 \mathrm{HB}$ & 832 & 19 & 6,8 \\
\hline & 3,680 & 2,520 & 0,010 & 0,030 & 0,290 & 1 & 1 & 1,360 & 1 & 1 & 1 & 1 & 1 & & & & & $32,2 \mathrm{HRc}$ & 1 & 14,4 & 1 \\
\hline 27 & 3,560 & 2,460 & 0,010 & 0,030 & 0,240 & 1 & 1 & 1 & 0,860 & 1 & 1 & 1 & 1 & 000 & 10 & 100 & $0: 3$ & $32,3 \mathrm{HRc}$ & 1 & 15,5 & 1 \\
\hline 31 & 3,730 & 2,460 & 0,010 & 0,030 & 0,470 & 1 & 1 & 1 & 1 & 1 & 1 & 1 & 1 & 900 & 1,0 & 400 & 0,83 & $31,5 \mathrm{HRc}$ & 1 & 15,7 & 1 \\
\hline & 3,530 & 2,530 & 0,020 & 0,040 & 0,250 & 0,350 & 1 & 1 & 1 & 1 & 1 & 1 & 1 & & & & & $33,3 \mathrm{HRC}$ & 1 & 12,0 & 1 \\
\hline
\end{tabular}

